Omni-Akuatika, 14 (2) : 73-78, 2018
ISSN: 1858-3873 print / 2476-9347 online
Research Article
journal homepage: http://ojs.omniaquatika.net

\title{
Effectively Of 17a-Methyltestosterone on Tropical Eel, Anguilla bicolor McClelland Masculinization in Different Salinity Culture
}

\author{
Farida Nur Rachmawati ${ }^{1}$, Ridwan Affandi ${ }^{2}$, Yulia Sistina ${ }^{3^{*}}$ \\ ${ }^{1,3}$ Faculty of Biology, Jenderal Soedirman. University Purwokerto, 53122, Central Java, Indonesia \\ ${ }^{2}$ Water Resources Management, Faculty of Fisheries \& Marine Science, IPB, Bogor, 16680, West Java, \\ Indonesia
}

"Corresponding author: yulia.sistina@unsoed.ac.id

\begin{abstract}
Eel population in nature reaches critical number, so that culture strategy is urgently needed to fulfil the high demand of this fish. A shortcut to get functional male, which proven difficult to be founded from natural catching, is masculinization. This research aimed to induce masculinization of tropical eel, Anguilla bicolor McClelland supplemented with various doses of $17 \alpha$-methyltestosterone during a month culture in freshwater $(0 \mathrm{ppt})$ or brackish water $(10 \mathrm{ppt})$. The eel was grouped and fed with supplementation of $17 \alpha$-methyltestosterone at various doses, depending upon treatments, namely 0 $\mathrm{mg} \mathrm{Kg}^{-1}$ diet (control), 40, 80 or $120 \mathrm{mg} \mathrm{Kg}^{-1}$ diet. Eels size were similar, at approximately $16,78 \mathrm{~g} \pm$ 0,62 in weight and $25,38 \mathrm{~cm} \pm 0,15$ in length were either culture in freshwater or brackish during the experiment for eight weeks. Sex gonad, based on anatomical histological structures, Eye Index and Fin Index were measured after time culture treatment achieved, as well as body length, weight, eye diameter and the length of the pectoral fin were measured. Results showed that supplementation $17 \alpha-$ methyltestosterone $80 \mathrm{mg} / \mathrm{Kg}$ diet culture in brackish water has the highest number of male $(90 \%)$. This study proven that, the hormone was effective for masculinization in eels, It useful for masculinization in eels. Results proved that the $17 a$-methyltestosterone highly significant $(P<0.01)$ effect on the Eye index $(3.63-5.14)$ and Fin Index $(3.03-4.08)$ of eels. This study concluded, that $17 \alpha$-methyltestosterone more effective in improving the number of males in brackish water than in freshwater culture.
\end{abstract}

Keywords: Eel, masculinization, 17a-methyltestosterone, salinity.

\section{Introduction}

Mature male eel is very important as mature female for artificial insemination as part of eel culture needed. Female broodstock in nature was easily founded, as compared to mature male in capture (Rachmawati and Susilo, 2011; Arai and Kadir, 2017). Information about natural eel maturation is lacking (Churcher et al., 2014). So, the male functional for broodstock by induction for eel culture purposes urgently needed.

The effectiveness use of male sex hormone, 17a-methyltestosterone has been reported for some purposes including to induce masculinization, as a mean of sex reversal, on Tilapia (Marjani et al, 2009; ) or on zebra fish (Orn et al., 2003), as well as for sex inversion in grouper fish (Sarter et al, 2006) use of the hormone as inplant to induce permanent sex inversion of 1-year-old juvenile protogynous dusky grouper (Epinephelus marginatus) resulted in complete sex change after 12 weeks, with the gonad organized in lobules and cysts filled with germ cells at all stage of spermatogenesis.

Masculinization, in term of getting functional male, not as a mean of sex revearsal, applied 17a-methyltestosterone on tropical eel has been reported. Rovara et al (2005) applied $17 \alpha$-methyltestosterone to eels of sizes 20-30 $\mathrm{cm}$ (yellow eel stage) with the doses of 0,100 and $200 \mathrm{mg} \cdot \mathrm{Kg}^{-1}$ diet for a month resulted in $80 \%$ population was male. To induce tropical eel maturation aplked the 17amethyltestosterone in combination with PMSG, $A D$ and MT of $100-150 \mathrm{gr}$ sizes (yellow eel stage), resulted in $100 \%$ male and enhanced the gonad maturity also has been reported by Aryani et al. (2015). As we aware ell life cycle is complex, consist of stages : larvae leptocephalus, young eel at glass eel, young eel of elver, young eel of yellow ell and adult of silver eel (Van den Thillart \& Dufour, 2009; Macri et al, 2014; Simon, 2015). This report assess effectiveness of the hormone applied on tropical eel of yellow eel (15 $-30 \mathrm{~cm}$ in length) 
to induce masculinization as a mean of maturation or functional male.

In European eel sexual maturity has been detected via metamorfosis processes including changes in skin colours, increase in body weight, and eye size culture in saltwater other than fresh water induce reproductive status better (Nowosad et al., 2014). Eel maturity status has been claimed for sometime can be seen from size of particular part including body length, particularly the Eye lindex and Fin Index increased during gonad maturity (Nowosad et al., 2014). As well as induce masculinization of eels, it is important to stimulate gonad maturity by rearing in the seawater. Effect of 17a-methyltestosterone on maturation characters of european eels has long ago reported as made darker skin in colour and enlarged of eye diameter (Olivereau and Olivereau, 1985). Methyltestosterone, an inhibitor of aromatase (Kitano et al., 2000). A

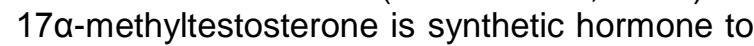
mimic natural testosterone functions, or male sex hormone, some function such as determination of secondary reproductive characters, induction of male maturation step processes, including function in male gametogenesis, etc.

The use of $17 \alpha$-methyltestosterone in sex reversal of zebrafish effective use the dose of 26-1000 $\mathrm{ngL}^{-1}$ (Orn et al., 2003). The 17amethyltestosterone effectively in large taxonomic fishes for sex reversal such as review by Pandian and Sheela (1995). The 17a-methyltestosterone also use to induced somatic growth in European eel give significant in liner growth of elver eel (Degani, 1986), as well as the hormone give linier increased in body composition of eel after dietary with the hormone treatment (Degani, 1985).

Histological male gonad of single male yellow wild giant mottled eel has been reported. (Anguila marmorata) having immature male germ cell (Matsubara et al., 2013), and the study proven that gonadal development correspond to their morphological changes. Early maturation stage of male gonad has also been reported in two freshwater eels as having seminiferous tubules with spermatogonia or in later stage with spermatocyte (Arai and Kadir, 2017). Freshwater eels of two species has similar maturation stage of male as characteristic by eye and fin (Arai and Kadir, 2017).

This research aimed to induce masculinization of tropical eel, Anguilla bicolor McClelland supplemented with various doses of 17a-methyltestosterone during eight weeks culture in freshwater (0 ppt) or brackish water (10 ppt), based on histological assessment data to determine the sex of eel results (histological structural sex determination of the gonad).

\section{Materials and Methos}

\section{Animal Handling}

The experimental animals, which homogenous eels of yellow eel stage, were obtained from PT LABAS, Bogor, then were acclimated for about a week on the fibre aquarium $\left(220 \times 120 \times 40 \mathrm{~cm}^{3}\right)$ filled with $528 \mathrm{~L}$ of freshwater. During the acclimation eels were fed with commercial pellet (PT LABAS Indonesia, Protein: 56.56\%; fat: $17.25 \%$; fibers: 2.29\%; Water: $4.85 \%$ and BETN: $5.70 \%$ ) satiated ad libitum. After the acclimation, eels were transferred to the experiment fibre aquarium $(40 \times 60 \times 60 \mathrm{~cm} 3)$ with 20 fishes per fibre aquarium according to the treatment. During experimentation, eels were fed with commercial pellet (PT LABAS Indonesia) once a day at $5 \mathrm{pm}$ as much as $3 \%$ of body weight and kept for 8 weeks (two months). The food were supplemented with various doses of Methyltestosterone 0, 40, 80, and $120{\mathrm{mg} . \mathrm{Kg}^{-1}}^{-1}$ diet and culture in freshwater (0 ppt) or brackish water (10 ppt).

\section{7a-Methyltestosterone Preparation for Diet}

Method for hormone preparation for diet was modification from Hendry et al. (2003). The Methyltestosterone (Sigma, M-7252) powder $40 \mathrm{mg}$ was dissolved in $10 \mathrm{~mL}$ of $70 \%$ Alcohol then were mixed thoroughly with one $\mathrm{Kg}$ commercial pellet with the help of water. Similar procedure for others doses, $80 \mathrm{mg}$ hormone or $120 \mathrm{mg}$ was dissolved in $10 \mathrm{~mL}$ $70 \%$ alcohol then each were mixed thoroughly by adding water as needed. Food contain hormone then was air dried during the day under sunlight, as modification methods of Hendry et al.(2003). Control group food was saturated with Alcohol only.

\section{Data Collection}

After week $8^{\text {th }}$ of treatments was achieved, eels were anesthetized with clove oil 5 ppm for about 30 minutes (Rachmawati \& Susilo, 2009). Then, each individual eel was weighed using technical scale, data recorded, it's length body was measured using a ruler, data recorded, eye diameter and pectoral fin length were measured using a calliper. Fish then were dissected through the abdomen from the anus to the pectoral for gonadal isolation. Gonad was weighed using an analytical scale 
(Explorer OHAUS) to get the GSI (Gonadosomatic Index).

The horizontal $(A)$ and vertical diameter (B) of the orbital eye were measured using a calliper, to get eye diameter. Eye Index is $\{(A+$ B) / 4\} $2 \times \pi /$ Body Length $(\mathrm{mm}) \times 100$ (Yokouchi et al., 2009). Measurement of pectoral fin length using a calliper by measuring the length of the fins (FL) ranging from base to tip. Fin index is FL $(\mathrm{mm}) /$ Body Length $(\mathrm{mm}) \mathrm{x}$ 100 (Yokouchi et al., 2009).

Each isolated gonad, marked by it's treatments, then was fixed in NBF solution for Paraffin Method preparation gonad sample follow by Haematoxylin-Eosin. All labelled fixed gonad were sent to the Research laboratory of Faculty of Medicine UNSOED for further processes. The analysis of gonadal histology structure refers to Arai \& Kadir (2017) to evaluate sex and gonad maturity status under microscope.

\section{Experimental Design}

This experimental study applied eight treatments with 20 replications as an individual unit. Eels were grouped and fed with supplementation of $17 \alpha$-methyltestosterone died at various doses, depending upon treatments, namely $0 \mathrm{mg} \mathrm{Kg}^{-1}$ diet (control), 40 , 80 or $120 \mathrm{mg} \mathrm{Kg}^{-1}$ diet. Eels size were approximately similar, averages size $16.78 \mathrm{~g} \pm$ 0.62 in weight and $25.38 \mathrm{~cm} \pm 0.15$ in length were either culture in freshwater or brackish during the experiment for two months. The observed variables were survival rate, sex (based on histological structure of gonad), Eye Index and Fin Index.

The research was conducted at Experiment Station and Animal Physiology Laboratory of Biology Faculty UNSOED from April to July 2017. Data obtained from the study: Eye index and fin index were analysed by one-way ANOVA and the number of males were analysed descriptively (Steel \& Torrie 1981).

\section{Results and Discussion}

The results showed the highest number of male $(90 \%)$ in the eel from treatment of $17 \alpha-$ methyltestosterone $80 \mathrm{mg} \cdot \mathrm{kg}^{-1}$ diet in brackish water culture whereas in the same doses, which culture in freshwater the number of a male only $55,56 \%$ (Figure 1 ).

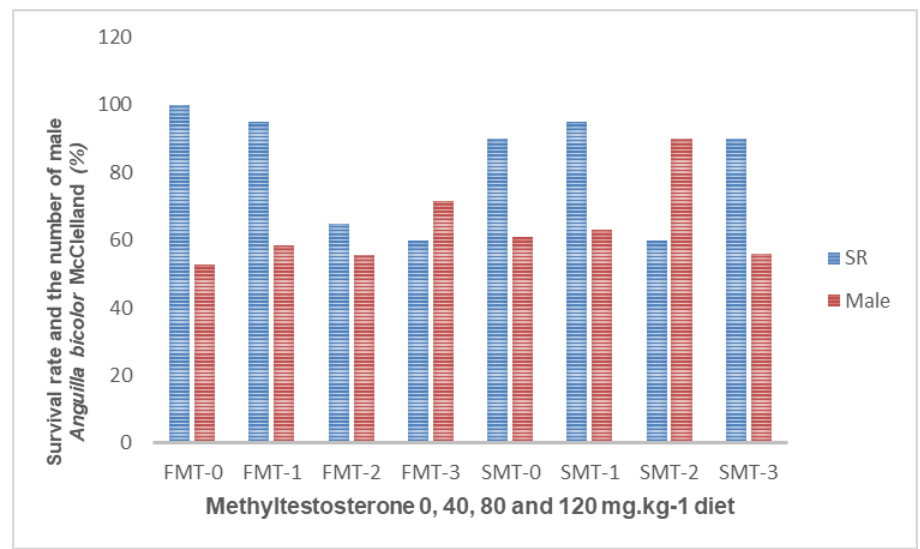

Figure 1. Survival rate (SR) and male number of the experimentation of Anguilla bicolor McClelland after 8 weeks supplemented with various doses of $17 \alpha$-methyltestosterone in freshwater $(0$ ppt) or brackish water (10 ppt). FMT-0: Methyltestosterone $0 \mathrm{mg} \cdot \mathrm{Kg}^{-1}$ diet in freshwater culture (control); FMT-1: Methyltestosterone $40 \mathrm{mg}^{-\mathrm{Kg}^{-1}}$ diet in freshwater culture; FMT-2: Methyltestosterone $80 \mathrm{mg} \cdot \mathrm{Kg}^{-1}$ diet in freshwater culture; FMT-3: Methyltestosterone 120 $\mathrm{mg} \cdot \mathrm{Kg}^{-1}$ diet in freshwater culture; SMT-0: Methyltestosterone $0 \mathrm{mg} \cdot \mathrm{Kg}^{-1}$ diet in brackish water culture; SMT-1: Methyltestosterone $40 \mathrm{mg} \cdot \mathrm{Kg}^{-1}$ diet in brackish water culture; SMT-2: Methyltestosterone $0 \mathrm{mg} \cdot \mathrm{Kg}^{-1}$ diet in brackish water culture; SMT-3: Methyltestosterone 120 $\mathrm{mg} \cdot \mathrm{Kg}^{-1}$ diet in brackish water culture. 


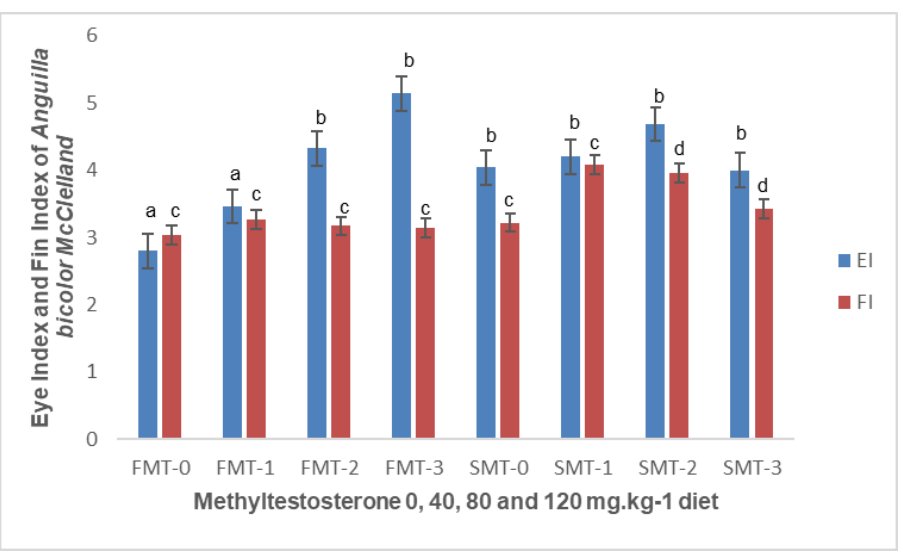

Figure 2. Eye Index (EI) and Fin Index (FI) of Anguilla bicolor McClelland supplemented with various doses of $17 \alpha$-methyltestosterone in freshwater (0 ppt) or brackish water (10 ppt). FMT-0: Methyltestosterone $0 \mathrm{mg} \cdot \mathrm{Kg}^{-1}$ diet in freshwater culture (control); FMT-1: Methyltestosterone $40 \mathrm{mg} \cdot \mathrm{Kg}^{-1}$ diet in freshwater culture; FMT-2: Methyltestosterone $80 \mathrm{mg} \cdot \mathrm{Kg}^{-1}$ diet in freshwater culture; FMT-3: Methyltestosterone $120 \mathrm{mg} \mathrm{Kg}^{-1}$ diet in freshwater culture; SMT-0: Methyltestosterone $0 \mathrm{mg} \cdot \mathrm{Kg}^{-1}$ diet in brackish water culture; SMT-1: Methyltestosterone 40 $\mathrm{mg} \cdot \mathrm{Kg}^{-1}$ diet in brackish water culture; SMT-2: Methyltestosterone $0 \mathrm{mg} \cdot \mathrm{Kg}^{-1}$ diet in brackish water culture; SMT-3: Methyltestosterone $120 \mathrm{mg} \mathrm{Kg}^{-1}$ diet in brackish water culture. Similar letter has no significant, different letter significant $(P<0.05)$ or higly significant $(P<0.01)$.

This study showed that $17 \alpha-$ methyltestosterone effectively induce male especially in marine or brackish water (Figure 1.). The 17a-methyltestosterone hormone, actually more effective for masculinization in freshwater culture than the marine or brackish culture one (Figure 1).

The 17a-Methyltestosterone improved eye index as well as the fin index significantly (Figure 2). Both data culture, freshwater and brackish water, significantly improve the eye and fin index (Figure 2.). This study also confirm earlier study that no real correlation between sex (male) and length (Table 1), except that eel of over $\geq 45 \mathrm{~cm}$ in length were females (Colombo et al., 1984; Colombo \& Grandi, 1990; Colombo \& Grandi, 1995; Tesch, 2003; Rachmawati \& Susilo, 2012; Rachmawati et al., 2017; Arai \& Kadir, 2017). In nature eel needs marine or brackish water to get maturation stage for reproduction, so we call eel as a catadromous species. This means that brackish water as an environmental factor for effective eel maturation factor. This study had been proven this natural phenomenon factor for eel maturation stage.

Table 1. Average ( \pm SD) of Lenght and Weight of tropical eel Anguilla bicolor McClelland before and after 8 weeks culture in fershwater or brakish one.

\begin{tabular}{lcccc}
\hline Treatments & $\begin{array}{c}\mathrm{BW}=0 \\
(\mathrm{~g})\end{array}$ & $\begin{array}{c}\mathrm{BW}=\mathrm{t} \\
(\mathrm{g})\end{array}$ & $\begin{array}{c}\mathrm{BL}=0 \\
(\mathrm{~cm})\end{array}$ & $\begin{array}{c}\mathrm{BL}=\mathrm{t} \\
(\mathrm{cm})\end{array}$ \\
\hline Control FMT0 & $22.95 \pm 3.5$ & $16.99 \pm 5.9$ & $25.06 \pm 1.0$ & $25.53 \pm 1.3$ \\
FMT 40 & $24.9 \pm 5.0$ & $14.79 \pm 3.3$ & $20.45 \pm 1.1$ & $25.02 \pm 1.2$ \\
FMT 80 & $21 \pm 3.0$ & $15.85 \pm 2.6$ & $24.73 \pm 1.5$ & $25.23 \pm 1.4$ \\
FMT 120 & $22.95 \pm 3.6$ & $14.5 \pm 2.3$ & $25.29 \pm 1.2$ & $25.47 \pm 1.1$ \\
Control SMT0 & $23.3 \pm 3.1$ & $25.44 \pm 13.8$ & $25.9 \pm 1.6$ & $26.53 \pm 2.5$ \\
SMT 40 & $21.9 \pm 3.5$ & $16.34 \pm 4.2$ & $25.43 \pm 1.4$ & $25.51 \pm 1.7$ \\
SMT 80 & $20.9 \pm 2.6$ & $15.08 \pm 2.8$ & $24.93 \pm 1.3$ & $24.49 \pm 1.1$ \\
SMT 120 & $20.75 \pm 3.4$ & $15.22 \pm 3.6$ & $24.64 \pm 1.4$ & $25.23 \pm 1.7$ \\
\hline
\end{tabular}


Results from LSD analysis of eye index and fin index data proven the effectiveness of the hormone. Results shown no hormone in fresh water culture (control) group was high significant different $(P<0.01)$ to all other 7 (seven) treatments, meaning that even low concentration and in fresh water culture, the hormone actually as effective as in brackish water culture induce masculinization of eel gonads. The hormone act as an aromatase inhibitor gene expression, and consequently the resultant decrease in the amount of natural oestrogen (Kitano et al., 2000). This possible explanation has been proven by histological data of this study showing male gonad structure, not the female one. In other word, this study proven that the hormone effectively induced a male gonad structure. Interesting finding from this study that the hormone gives different response in freshwater as compared to higher salinity water results.

The concentration of 17aMethyltestosterone $80 \mathrm{mg} \mathrm{Kg}^{-1}$ diet gave the highest number of males, so that the normal curve had been achieved from 4 doses applied. Contrary, male number from freshwater culture give linier curve result, the highest the hormone concentration give the highest number of male (Figure 1). This study confirms previous report on other eel that salinity culture better than freshwater one. In other word this finding support hypothesis of Nowosad et al. (2014) that saltwater gives better result than freshwater in inducing maturation reproduction of European eel. This tropical eel finding also give similar phenomenon that the brackish water culture is better than the fresh water culture.

\section{Conclusion}

This study concluded, that 17amethyltestosterone more effective in improving the number of males in brackish water than in freshwater culture.

\section{Acknowledgement}

Thank you to Ministry of Risset, Technology and Higher Education of Republic of Indonesia for funding this research in 2016.

\section{Authors' contributions}

FNR, RA, and YS design the study. FNR and $Y S$ analysed data and wrote manuscript.

\section{References}

Arai T, \& Kadir, ASR. 2017. Opportunistic spawning of tropical anguillid eels Anguilla bicolor bicolor and $A$. bengalensis bengalensis. [Internet]. [cited 2017 Nov 30]; 7:41649. Available from: http://www.nature.com/Scientificreport/ doi: $10.1038 /$ srep41649

Aryani, N.M., Sudrajat, A.O., Carman, O. 2015. Induced maturation of eel weight 100-150 gram with anti-dopamine, and 17amethiltestosterone. Jurnal Akuakultur Indonesia. 14 (2): 135-143.

Colombo, G., Grandi, G. \& Rossi, R. (1984). Gonad differentiation and body growth on Anguilla anguilla L. Journal of Fish Biology. 24 (2) : 215 - 228.

Colombo, G. \& Grandi, G. (1990). Gonad sex differentiation of Anguilla anguilla by sex steroids. Int. Revue ges. Hydrobiol, 75(6) : 763- 773.

Colombo, G. \& Grandi, G. (1995). Sex differentiation in the European eel : histological analysis of the effect of steroids on the gonad. Journal of Fish Biology. 47 : $394-413$.

Churcher, A.M., J.M. Pujolar, M. Milan, P.C. Hubbard, R.S.T. Martins, J.L. Saraiva, M. Huertas, L. Bargelloni, T. Patarnello, I.A.M. Marino, L. Zane \& A.V.M. Canario. 2014. Changes in the gene expression profiles of the brains of male European Eels (Anguilla anguilla) during sexual maturation. BMC Genomic. 15 : $799-$ 812

Degani, G. 1985. The Influence of 17aMethyltestosterone on body composition of eels (Anguilla anguilla L). Aquaculture. 50: 23-30.

Degani, G. 1986. Effect of dietary 17ßOestradiol and $17 \alpha$-Methyltestosterone on growth and body composition of slow-growing elvers (Anguilla Anguilla L). Comp Biochem Physiol. 85 A (2): 243-247.

Hendry, C., Martin-Robichaud, D.J., Benfey, T.J. 2003. Hormonal sex reversal of Atlantic halibut (Hippoglossus hipoglossus L). Aquaculture 219(1-4) :769-781

Kitano, T, K. Takamune, Y. Nagahama, S. Abe. 2000. Cause sex-reversal from genetic females to phenotypic males and suppressions of P450 aromatase gene expression in Japanese Flounder 
(Paralichthys olivaceus). Molecular Reproduction and development 56:1-5

Marjani, M., S. Jamali, P.G. Moestafavi, M. Ramin \& A. Mashinchian. 2009. Influence of 17-alpha mehyltestosterone on masculinization and growth in Tilapia (Oreochromis mossambicus). Journal of Fisheries and Aquatic Science 4(1): 71 74.

Macri, F., G. Rapisarda, C. De Stefano, M. De majo, T.Bottari \& G. Aiudi. 2014.Coelioscopic investigation in European eels (Anguilla anguilla). Journal of Exotic Pet Medicine, 23 : 147 151.

Matsubara, H., Kubara, Y., Yoshikawa, H., Iwata, D., Shimizu., Horie, Y., Imai, T., Fukuoka, Y., Watanabe, K., Shione, H. 2013. Gonadal histology of wild giant mottled eel Anguilla marmorata in Okinawa Japan. Biogeography 15, 55-62

Nowosad J, Kucharczyk D, Czarkowski TK, Kwasek K. 2014. Changes in body weight and eye size in European eel kept in fresh and salt water. Italian Journal of Animal Science 13, 382-86

Olivereau, M., Olivereau, J.1985. Effect of 17amethyltestosterone on the skin and gonads of freshwater male silver eels. General Comparative Endocrinology 57, 64-71.

Orn, S., Holbech, H., Madsen, T.H., Norrgren, L., Petersen, G.I. 2003. Gonad development and vitellogenin production in zebrafish (Danio reiro) exposed to ethynylestradiol and methyltestosterone. Aquatic Toxicology 65: 397-411.

Pandian, T.J. \& S.G. Sheela. 1995. Hormonal induction of sex reversal in fish. Aquaculture 138: 1 - 22.

Sarter, K., M. Papadaki, S. Zanuy \& C.C. Mylonas. 2006. Permanent sex inversion in 1-year old juveniles of the protogynous dusky grouper (Epinephelus marginatus) using controlled-release 17amethyltestosterone implants. Aquaculture, $256: 443-456$.

Rachmawati FN \& Susilo U. 2009. Perkembangan Gonad Ikan Sidat, Anguilla bicolor Ditinjau dari Titer Hormon Gonadotrophin. Sains Akuatik 10(2):148-54.

Rachmawati FN \& Susilo U. 2011. Profil Hormon dan Kinerja Reproduksi Ikan sidat, Anguilla bicolor McClelland. Biota 16(2): 221-26.

Rachmawati, F.N \& U. Susilo. 2012. Kajian Histologi Ikan Sidat, Anguilla bicolor McClelland, yang tertangkap di Segara Anakan Cilacap. Berkala Penelitian Hayati, 18 (1) : 47-49.

Rachmawati, F.N. \& Susilo U, Muslih. 2017. Karakteristik reproduksi ikan sidat Anguilla bicolor McClelland, 1844 yang diinduksi $\mathrm{GnRH}$-analog. Jurnal Iktiologi Indonesia. 17(2):155-63

Rovara, O. 2005. Penggunaan Hormon Methyltestosteron untuk maskulinisasi elver ikan sidat (Anguilla bicolor bicolor) Dari Perairan Estuaria Segara Anakan. Alami 10 (3): $40-43$

Simon, J. 2015. Age ad growth of European eels (Anguilla anguilla) in the Elbe River System in Germany. Fisheries Research, $164: 278-285$.

Tesch FW. (2003) The Eel. Blackwell Science, Oxford, UK, $408 \mathrm{pp}$.

Van den Thillart, G. \& S. Dufour. 2009. How to estimate the reproductive succes of European silver eels. In : G. Van den Thillart, J.Rankin \& S. Dufour (eds) Spawning Migration of the European Eel. Springer, Netherland. Pp. 3 - 9.

Yokouchi, K., Sudo, R., Kaifu, K., Aoyama, J., Tsukamoto, K. 2009. Biological characteristics of silver-phase Japanese eels, Anguilla japonica, collected from Hamana Lake, Japan. Coastal Marine Science 33(1): 1-10 